\title{
SOME INTERRELATION BETWEEN MICROBIAL XYLANASE AND GLUCOSE ISOMERASE PRODUCTION
}

\author{
YONG K. PARK AND MASAKO TOMA \\ Universidade Estadual de Campinas, Faculdade de Tecnologia de Alimentos, Campinas, Brasil
}

(Received August 14, 1973)

Streptomyces pheochromogenes has been shown to produce glucose isomerase when this organism is grown in culture medium containing xylose (1). Later, TAKASAKI (2) reported that Streptomyces albus produces glucose isomerase when the organism is grown in the culture medium containing either xylose or xylan. Recently, we have isolated Streptomyces sp. from the Campinas area of Brazil. This particular strain produces intracellular glucose isomerase when grown in a medium containing either xylan or xylose. Furthermore, xylanase is produced when the organism is grown in a medium containing xylan, but the strain does not produce xylanase in the culture medium containing only xylose.

The Streptomyces sp. isolated from the soil was incubated in 250-ml Erlenmeyer flasks containing $50 \mathrm{ml}$ of culture medium in a controlled environment incubator shaker (New Brunswick Scientific Co.). Conditions of incubation was $30^{\circ}$, $250 \mathrm{rpm}$, and for $56 \mathrm{hr}$. Two culture media were used. Culture medium 1 contained $0.25 \%$ yeast extract, $0.5 \%$ beef extract, $1 \%$ peptone, $0.5 \% \mathrm{NaCl}, 1 \%$ xylose, and $0.05 \% \mathrm{MgSO}_{4} \cdot 7 \mathrm{H}_{2} \mathrm{O}$, and culture medium 2 consisted of $0.25 \%$ yeast extract, $0.5 \%$ beef extract, $1 \%$ peptone, $0.5 \% \mathrm{NaCl}, 0.5 \%$ xylan, and $0.05 \%$ $\mathrm{MgSO}_{4} \cdot 7 \mathrm{H}_{2} \mathrm{O}$.

Xylanase activities were measured by the method described by KaWAMINAMI and IrzuKa (3); $2.5 \mathrm{ml}$ of $0.5 \%$ xylan solution, $2.5 \mathrm{ml}$ of acetate buffer $(0.05 \mathrm{~mol}$, $\mathrm{pH} 4.0$ ), and $1 \mathrm{ml}$ of enzyme solution were mixed and incubated at $50^{\circ}$ for $30 \mathrm{~min}$ in a water bath. Reducing substances were determined by the method described by Somogyi (4) and by NeLSON (5). The activity of xylanase was expressed in terms of the amount of sugar produced.

Glucose isomerase activities were measured by the cysteine-carbazole method, which was reported by Dische and Borenfreund (6). The activity of glucose isomerase was expressed in terms of the amount of fructose produced.

Periodically (every $5 \mathrm{hr}$ ), a $15-\mathrm{ml}$ sample was taken from each Erlenmeyer 
flask, and it was centrifuged to separate the cells and supernatant. One $\mathrm{ml}$ of the supernatant solution was used to measure the xylanase activity. The precipitated cell mass was suspended in distilled water and centrifuged again. This procedure was repeated three times. The final cell suspension in distilled water was used for determination of glucose isomerase activity. Alternatively, cell suspension in distilled water was sonified and centrifuged at $10,000 \mathrm{rpm}$ for $10 \mathrm{~min}$, and the



Fig. 1. Time course of incubation in presence of xylan. $-\times-$, Xylanase activity; $\cdots \bigcirc \cdots$, Glucose isomerase activity; $-\triangle-$, Cell growth.

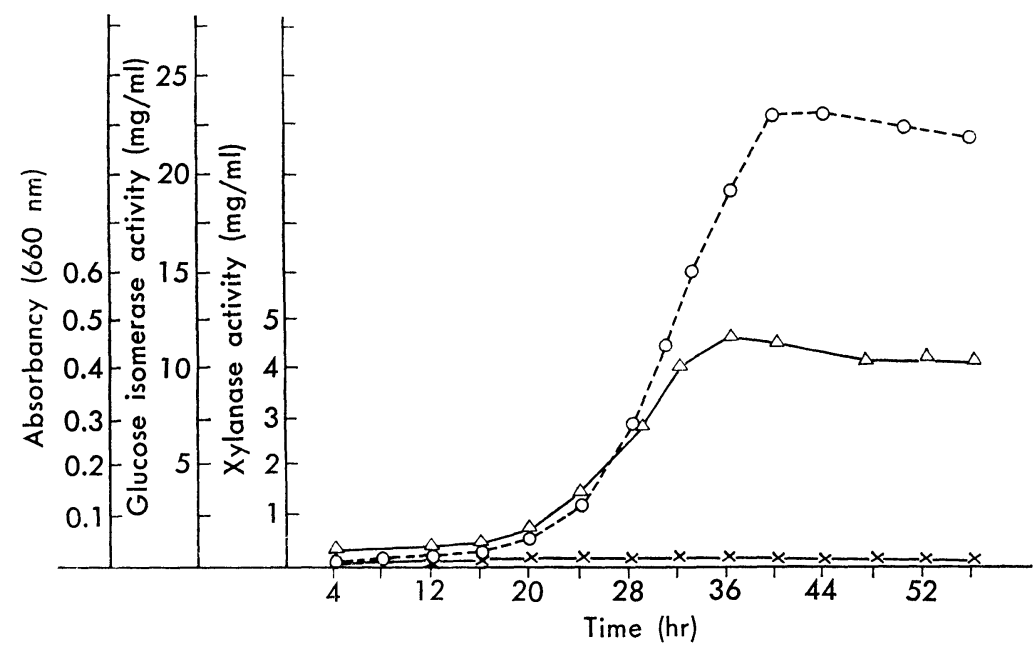

Fig. 2. Time course of incubation in presence of xylose. - - - , Xylanase activity; $\cdots \circ \cdots$, Glucose isomerase activity; $-\triangle-$, Cell growth. 
supernatant solution was also used for determination of enzyme activity. The cell growth was measured by determining the absorbancy of cell suspension in distilled water at $660 \mathrm{~nm}$. Figure 1 shows the time course of incubation in culture medium 1, which contains only xylose as carbohydrate. Glucose isomerase was produced but no production of xylanase was observed. Figure 2 illustrates the time course of incubation in culture medium 2, which contains only xylan as carbohydrate. In the presence of xylan, both glucose isomerase and xylanase were produced. This clearly demonstrates that xylan induced the production of xylanase. Therefore, we believe that an interrelation exists among the production of glucose isomerase, production of xylanase, and xylan. We are working further on this phenomenon.

\section{REFERENCES}

1) N. Tsumura, M. Hagi, and T. Sato, Agr. Biol. Chem. (Tokyo), 31, 902 (1967).

2) Y. TAKasaki, Agr. Biol. Chem. (Tokyo), 30, 1247 (1966).

3) T. Kawaminami and H. Irzuka, J. Ferment. Technol., 48, 161 (1970).

4) M. J. Somogyi, J. Biol. Chem., 160, 61 (1945).

5) N. J. Nelson, J. Biol. Chem., 153, 375 (1944).

6) Z. Dische and E. A. Borenfreund, J. Biol. Chem., 192, 583 (1951). 